\title{
The Triple Bottom Line (TBL) studies towards Sustainability Marketing
}

\author{
Zalinawati Abdullah \\ UiTM Cawangan Terengganu \\ Dungun, Malaysia. \\ zalin5026@tganu.uitm.edu.my \\ Wan Maziah Wan Ab Razak \\ UiTM Cawangan Terengganu \\ Dungun, Malaysia. \\ wanma558@tganu.uitm.edu.my \\ Haslenna Hamdan \\ UiTM Cawangan Terengganu \\ Dungun, Malaysia \\ has@tganu.uitm.edu.my
}

\author{
Ahmad Ismail Mohd Anuar \\ UiTM Cawangan Terengganu \\ Dungun, Malaysia \\ ahmadima@tganu.uitm.edu.my \\ Nurul Aini Aziz \\ UiTM Cawangan Terengganu \\ Dungun, Malaysia \\ zalin5026@tganu.uitm.edu.my
}

\begin{abstract}
The research was conducted to investigate the implementation of marketing sustainability among customer. Sustainability is a collective term for everything to do with responsibility for the world in which we live. The study focusing on the relationship between three elements of Triple Bottom Line (TBL) namely; environment, social and economy towards the sustainability marketing. A total of 306 respondents were among customers at Terengganu Equestrian Resort (TER). Data collected were analyzed by using Descriptive Statistic (Frequency) and Inferential Statistic (Correlation) in statistical package for social science (SPSS) version 20 was used to test the result. Among three independent variables, only two are proved to have significant relationship towards sustainability marketing with strong or very strong coefficient correlation statically significant at 0.000 . By using multiple regression analysis, economy dimension was the most influential factor towards sustainability marketing.
\end{abstract}

Keywords-Triple Bottom Line; environment; social and economy and sustainability marketing

\section{INTRODUCTION}

Increasing number of people in the world from year to year make us living far beyond the earth's capacity to support us. As a consequence, environment pollution becomes more serious issue due to pollution of air, temperature, water and even animal habit was change. Authority such as marketers and decision makers try to find out what can they make for at least people can get basic quality of life in the future. Nowadays, people are facing difficulties regarding changing of environment. Earthquake, storm, pollution and many other factors can be the reason why environment can change drastically.

Sustainability marketing is also known as green marketing is one of the strategies comes out by the marketers. Instead of only selling product, sustainability marketing offer broadly thinking of the socio and the eco-environment. Sustainability marketing also involves promotion, sales, and distribution of products and services but at the same time also include protection to the environment [1].

Sustainability marketing increased environmental awareness by positioning awareness in the consumer mind. Sustainability is closely related to Corporate Social Responsibility (CSR) even some people think it was the same thing. The differences between the two have been debated for a long time. When comparing them, the one difference that is primarily pointed out is that sustainability relates to making a company a greener, more energy efficient operation, in addition to taking care of people and profit. Sustainability includes a commitment to protecting the environment, in addition to community and economic success, whereas traditionally, CSR does not include the commitment to the environment [2].

\section{A. Background of Company}

Yayasan Kebajikan Perkasa Alam (YKPA) has acquired rights from the State Government to develop an Equestrian Center, Sports, and Recreation in Kuala Ibai Lagoon, Kuala Terengganu. The center is known as the Terengganu Equestrian Resort (TER), which is managed by subsidiary of YKPA is Alam Laguna Management Sdn. The Chairman of the company Alam Laguna Management Sdn Bhd is Dato' Hamzah Bin Muhammad and has approximately 100 employees.

TER provides facilities and services such as accommodation at Paddock Inn (resort), sports facilities such as equestrian for riding horse, bowling, badminton, swimming pool, table tennis, squash, netballs, and gymnasium at Sports 
Complex. In addition, provide many facilities or service to customer such as hall rooms for seminars, weddings, dinner at the Club House (Balai Kenanga, Sri Mawar, Sri Melor, Laman Polo, Anjung Polo, Sri Cempaka, Sri Melati) and also Paddock Café providing local and international food at reasonable prices. Terengganu Equestrian Resort customers are open to all public and foreign tourists consisting of government agencies, private corporations, individuals, and groups.

\section{B. Statement of Problem}

Nowadays, sustainability has been the important goal of business, nonprofit company, and government. Business prefers to use the TBL and its core value of sustainability for their long-term profit. Policymaker uses the sustainability assessment frameworks to decide what kind of actions they should or not should take to make society more sustainable and environment protection.

Furthermore, in Malaysia the statistic reveals that 45 percent out of 33,000 tons of solid waste are dumped every day as food waste. The food waste that disposed of in landfills together with other organic materials, it will produce the greenhouse gas methane that contributed to the global warming [3].

A well-known corporate sustainability strategy is Marks \& Spencer's Plan A. They grouped their sustainability challenges under five headings:

1. Climate change

2. Waste

3. Sustainability sourcing

4. Ethical trading standards

5. Helping consumers \& employees live a healthier lifestyle

Consumer awareness of environment protection is still lack. Some consumer even does not have awareness of the importance to protect the environment. They just need things that can satisfy them without thinking the implication to the earth and the future. From this sustainability marketing idea at least consumers get an idea why environmental protection is important.

\section{Research Objectives}

The objectives of this research have been determined as follows:

1. To investigate the relationships between TBL (environment, social and economy) towards sustainability marketing.

2. To identify the most influential variable towards sustainability marketing.

\section{Scope of the Study}

The research focuses on the influence of TBL towards sustainability marketing. There are three Independent variables such as environment, social and economy.

All the information and knowledge have been investigated by using all the data from the company, cooperation with all the staff and sales advisor, communication with the customer and also involved expert guide.

The researcher had decided to choose Terengganu Equestrian Resort (TER) as the place to carry out research. The research was conducted among customer who came and received service provided by TER and also those who used the sports facilities in the sports complex.

The respondents of this study were selected customer from TER because the researcher wants to identify feedback and respond from the customer about service provided by TER.

The researcher chose the month of April for the year 2014 as a number of population. From the number of population, will refer to [4] to identify the total number of sample size that should be investigated. According to the sport and recreation department, estimated number of customer approximately 1,500 packs of customers. Total number population is 1,500 and sample size will be 306 samples of customers.

\section{II.LITERATURE REVIEW}

\section{A. Sustainability Marketing}

Market systems are supposed to respond to consumer demand to produce a desirable standard of living. However, a market system also generates externalities that challenge its existence and threaten desired standards of living. Frequently, there is also a lag between what the system produces and evolving consumer demand. These externalities and this lag, which are currently inducing a commons effect in the global ecosystem [5].

Modern marketing can be briefly defined as "managing profitable customer relationships" which implies attracting new customers by promising higher value as well as keeping current customers by delivering satisfaction [6].

Product is market successfully if the marketer understands the needs and wants of the consumer, develops products that provide superior value and prices, promotes and distributes them effectively. Sustainable development is a kind of development that meets the needs of the present without compromising the ability of future generations to meet their own needs [7].

The concept of sustainable development implies intragenerational equity (i.e., equality between North and South) and inter-generational equity (i.e., between one generation and another). There are three dimensions of sustainable development: environmental, social and economic. A major challenge for companies is to integrate and balance the three aspects of sustainability in a responsible way. They have to maintain financial stable and competitive while including ecological requirements and social demands. This is particularly true for sustainability marketing, which may be defined as "building and maintaining sustainable and profitable relationships with customers, the social environment, and the natural environment" [8]. 
The words "sustainability" and "sustainable development" has become the latest thing in the last decade. There are numerous conferences with "sustainability" in their titles. In fact, the Conference Alert website identifies 119 sustainable development conferences worldwide between February and December 2013. The number of publications and articles related to sustainable development has increased significantly. With all of these conferences and publications, one would assume that there is a common understanding of the terms and their meaning amongst the general public. However, in discussions with non-academic and individuals not involved with sustainable development, it seems there is no clear results come out would find of what the terms mean.

Sustainability is a collective term for everything to do with responsibility for the world in which we live. It is an economic, social and environmental issue. It is about consuming differently and consuming efficiently. It also means sharing between the rich and the poor and protecting the global environment while not jeopardizing the needs of future generations.

Sustainability refers to "development that meets the needs of the present without compromising the ability of future generations to meet their own needs". In fact, this topic has become an attractive method for business to view its responsibilities through the Triple Bottom Line (TBL), a perspective based on three important dimensions: environmental quality, social equity, and economic prosperity. Similar to more established marketing research, these dimensions can be viewed as the basis for integral marketoriented resources, capabilities, and competitive advantage in comparison with marketplace competitors.

\section{B. Triple Bottom Line}

Triple Bottom Line (TBL) as the main topic in this research which consists of environment, social and economy. The social include five aspects which are reducing products energy consumption, packaging materials, hazardous substances, weight, increasing level of recycling and safeguards during disposal of products. The social is concerned with the comfort of people and communities [9]. Meanwhile, the economy include personal income, unemployment rate, redevelopment and job growth [10].

\section{ENVIRONMENTAL}

First dimension in Triple Bottom Line (TBL) is environmental quality. Environmental variables should represent measurements of natural resources and reflect potential influences to its viability. It could incorporate air and water quality, energy consumption, natural resources, solid and toxic waste, and land use/land cover. Ideally, having longrange trends available for each of the environmental variables would help organizations identify the impacts a project or policy would have in the area[10].
Currently, environmental sustainability is a topical issue that receives plenty of attention from the media and different governmental departments. This is a result of the amount of research going into assessing the impact that human activity can have on the environment. Although the long term implications of this serious issue are not yet fully understood, it is generally agreed that the risk is high enough to merit an immediate response. Businesses are expected to lead in the area of environmental sustainability as they are considered to be the biggest contributors and are also in a position where they can make a significant difference.

\section{SOCIAL}

Second variable is social equity. 'Social Sustainability for a city is defined as development which is compatible with the harmonious evolution of civil society, fostering an environment conductive to the compatible contribution of culturally and socially diverse groups while at the same time encouraging social integration with improvements in the quality of life of all segments of the population [11].Social sustainability which requires that the cohesion of society and its ability to work towards common goals be maintained. Individual needs, such as those for health and well-being, nutrition, shelter, education and cultural expression should be met [12] .

Social sustainability occurs when the formal and informal processes, systems, structures and relationships actively support the capacity of current and future generations to create healthy and liveable communities. Socially sustainable communities are equitable, diverse, connected and democratic and provide a good quality of life [13].

Socially responsible marketing is a complex and emotional societal issue based on values and morals, which goes beyond managers' responsibilities to shareholders and their responsibility to manage their affairs as efficiently as possible. A study has found that the social responsibility of corporate marketers is an acceptance of accountability to meet the economic, legal, ethical, and philanthropic expectations of society for the behavior of the firm. This accountability extends to the assessment and reporting of the firm's activities and their social, ethical, and environmental consequences for stakeholders [5].

\section{ECONOMIC}

Third variable is economic. With the enduring global recession, consumers and society are deeply and urgently concerned with economic sustainability due to fear of widespread job losses, insecurity, and financial risk [14] . there are two distinct aspects of the economic dimension of sustainability: one related to conventional financial performance and the other relating to economic interest of external stakeholder such as broad-based improvement in economic well-being and standard of living [9].

\section{Research Framework}


Sustainability marketing consists of Triple Bottom Line which is environment, social and economy.

Figure 1. Research Framework

Independent Variables

Dependent Variable

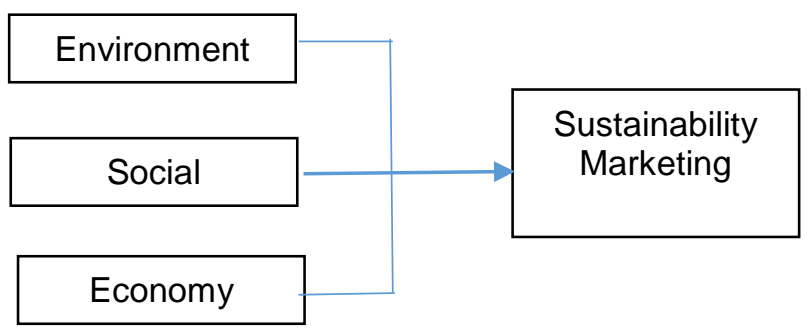

\section{RESEARCH DESIGN}

The descriptive study is undertaken for this study to collect data that describe the background of consumer and also investigate the relationship between the TB namely; environment, social and economy with sustainability marketing. Data collected and analyzed from descriptive research can help researcher understand the characteristic of a group. It can offer a clear picture of all aspects of investigation areas and contribute the new ideas [15]. This research design used to identify the relationship between TBL and sustainability marketing form customers' perspective.

\section{A. Sampling Procedure}

Research strategies for this study is a survey that defines as a system for gathering information from the customers to explain their behavior. The one shot or cross-sectional studies is undertaken for this study in which data gathered just once within two months.

\section{B. Population}

The population for this study is all customers in TER, Terengganu.

\section{Unit of analysis}

The unit analysis of this study is selected customer from TER.

\section{Sampling and sampling technique}

Traditional sampling approaches are being used in this research. The entire sample is selected before data collection is begins. For sampling techniques for this study is convenience sampling technique and target sample is customer used the service provided by Terengganu Equestrian Resort at the sports complex. There are few types of facilities that provided in the sports complex such as bowling, badminton court, gymnasium, swimming pool, squash, table tennis and others.

\section{E. Data Collection}

In conduct the research, the data must collect very systematically, there are many procedures must be following by the researcher. The pilot study has been conducted within two weeks for reliability and validity of the questionnaire.

\section{F. Research Instruments}

The questionnaire was used as the primary data collection. It was a self-constructed questionnaire containing 36 questions divided into two parts. Part one is about profile of respondents. Then, part two more details about independent variable. In the second part, there are five sections which are B, C, D, E \& F.

Types of questions was applied in part two is Likert-scale questions. There were about sustainability marketing (dependent variable), then, others about the independent variable which is environmental, social, economy and addition to customer satisfaction. For answers to the statement of survey, a Likert-type metric, ten intervals has been used which is "1-Extremely Disagree, 2-Strongly Disagree, 3-Slightly Disagree, 4-Disagree, 5-Moderate, 6-Moderate, 7-Agree, 8Slightly Agree, 9- Strongly Agree and 10- Extremely Agree.

Part 1 (Profile of Respondents)

Section A contains questions about respondents background which is demographic factors. The respondents were required to tick $(/)$ in the space provided such as gender, race, age, customer status, types of customer, monthly income and type of facilities using.

\section{G. Hypotheses of the study}

Hyphotesis 1

There is significant relationship between environment and sustainability marketing.

Hypothesis 2

There is significant relationship between social and sustainability marketing.

Hypothesis 3

There is a significant relationship between economy and sustainability marketing.

\section{IV.FINDING AND DATA ANALYSIS}

Based on 306 populations, the researcher had successfully distributed 315 questionnaires to all respondents, and there were 310 questionnaires was exactly returned. However, only four questionnaires discarded due to some missing information after coding and editing process was completed, the research team moved on to analyze the entire questionnaire.

\section{A. Reliability Analysis}

Table 1 shows the result of reliability test where the Cronbach 's Alpha reliability coefficient is obtained for the variables. The data collected was subjected to reliability 
analysis to establish the reliability of measure to each section in the questionnaires. Cumulatively, according to the table by [16] the strength of the Alphas are the range of very good for sustainability marketing, environment, social and economy. Since the Alpha value displayed the score more than 0.7, therefore proceed with analysis.

TABLEI: Reliability Coefficient Alpha from Section B, C, D, E

\begin{tabular}{|l|c|c|}
\hline & $\begin{array}{c}\text { Cronbach's } \\
\text { Alpha }\end{array}$ & Number of Items \\
\hline $\begin{array}{l}\text { Sustainability } \\
\text { Marketing }\end{array}$ & 0.964 & 6 \\
\hline Environment & 0.736 & 6 \\
\hline Social & 0.795 & 6 \\
\hline Economy & 0.644 & 5 \\
\hline
\end{tabular}

\section{B. Frequency Analysis}

Researchers have used this frequency distribution to analyze the personal data of the respondent with the classifications variables. In this research, all data will be collected on section A that is respondents profile in the part of the questionnaire. This frequency analysis will show the details amount in percentage with data giving by the respondents. Besides that, frequency analysis will show review all sample explored that must be investigated by the researcher.

TABLE II: Frequency output for respondents demographic profile (Section A)

\begin{tabular}{|l|c|c|}
\hline \multicolumn{1}{|c|}{ Profile } & Frequency & $\%$ \\
\hline Gender & 171 & 55.9 \\
Male & 135 & 44.1 \\
Female & & \\
\hline Age & 40 & 13.1 \\
Below 20 years & 198 & 64.7 \\
21 to 30 years & 44 & 14.4 \\
31 to 40 years & 16 & 5.2 \\
41 to 50 years & 6 & 2.0 \\
51 to 60 years & 2 & 7 \\
61 and above & 288 & 94.1 \\
\hline Race & 16 & 5.2 \\
Malay & 2 & 7 \\
Chinese & 0 & 0 \\
Indian & & \\
Others & 255 & 83.3 \\
\hline Customer Status & 51 & 16.7 \\
Repeat Customer & & \\
First Time Customer & 70 & 22.9 \\
\hline Type of Customer & 148 & 48.4 \\
Government & 28 & 9.2 \\
Private & 60 & 19.6 \\
Individuals & 0 & 0 \\
Students & 75 & \\
TER Staff & 20 & 26.1 \\
\hline Income & 9 & 39.9 \\
0-999 & & 6.5 \\
1000-1999 & & 2.9 \\
2000-2999 & & \\
3000-3999 & & \\
4000 above & & \\
\hline
\end{tabular}

TABLE II. Cont

\begin{tabular}{|l|c|c|}
\hline Type of Facilities & 209 & 68.3 \\
Bowling & 37 & 12.1 \\
Gymnasium & 34 & 11.1 \\
Swimming Pool & 19 & 6.2 \\
Badminton & 7 & 2.3 \\
Others & 7 & \\
\hline
\end{tabular}

Based on table 2, it is clearly stated that the number of male and female respondents are 171 and 135 respectively. Total of respondents are 306 . From the result, it shows that male is the majority customers at TER. This indicates that $55.9 \%$ of the respondents are male whereas the balances $44.1 \%$ are female respondents. Based on the table above, it shows that most of the respondents are in age 21-30 years old which is equal to $64.7 \%$ of the respondents. There are $13.1 \%$ respondents are below 20 years old, $14.4 \%$ respondents are between 31-40 years old, 5.2\% respondents are between 41-50 years old, 2\% respondents are between 51-60 years old, and $7 \%$ of respondents are more than 61years and above. From the table above Malay is 288 respondent (94.1\%), Chinese 16 respondents $(5.2 \%)$, Indian 2 respondents $(7 \%)$ and there are no others respondents. Repeat customers indicate 255 respondents which is $83.3 \%$ meanwhile first time customers is 51 which is $16.7 \%$. Then, 70 respondents are work at government agencies (22.9\%), 148 respondents work at private firm (48.4\%), 28 are individuals (9.2\%), 60 respondents are students $(19.6 \%)$, and TER staff are zero. From the data above, it shows that average salary of the respondents are between RM1000-RM1999. This indicates 122 respondents which is equal to $39.9 \%$ from the whole respondents. There are 80 respondents that income level below RM1000, 75 respondents who have income level which are RM2000-RM2999, 20 respondents who have income level RM3000-RM3999. All of them indicate $26.1 \%$ for income below RM1000, 24.5\% get RM2000-RM2999, $6.5 \%$ get RM3000-3999 and 2.9\% get RM4000 above. From the data indicates that majority respondents are using bowling facilities at TER which is $209(68.3 \%)$, gymnasium are $37(12.1 \%)$, swimming pool are $34(11.1 \%)$, badminton are $19(6.2 \%)$, and 7 are others $(2.3 \%)$

\section{Pearson Correlation (Coefficient Of Correlation)}

Pearson correlation was used to assess the relationship among variables TBL and sustainability marketing.

TABLEIII: Correlation among variables

\begin{tabular}{|c|c|c|c|c|}
\hline & A & B & C & D \\
\hline Sustainability Marketing (A) & 1 & $.311^{*}$ & -.074 & $.255^{*}$ \\
\hline Environment (B) & & 1 & .078 & $.280^{*}$ \\
\hline Social (C) & & & 1 & $.426^{* *}$ \\
\hline Economy (D) & & & 1 \\
\hline
\end{tabular}

*Correlation is significant at the level 0.01 level (2-tailed) 
Table 3 shows the result indicating that two dimensions of TBL (Environment and economy) are statistically significant with p-value of 0.000 at 0.01 significant levels. The analysis on the strength of association revealed that environment was at $\mathrm{r}=0.311$, is indicating that this dimension is weak correlation with sustainability marketing. Followed by economy with $\mathrm{r}=0.255$. However, a social dimension shows that there is no correlation towards sustainability marketing.

\section{Multiple-regression Analysis}

Regression is a technique that becomes as a subsequence after the correlation coefficient measure. It also tells us if a relationship exists between two variables as well as the overall strength of associated.

Based on table 4 below, it shows the analysis of sustainability marketing, environmental, social and economy. All the output that has been analyzed is resulting significant positive relationship exists between dependent variables and all the independent variables except for social. The significant value is $\mathrm{p}<0.05$, one tailed and it will determine very strong relationship between all the variables.

TABLEIV: Summary of regression analysis

\begin{tabular}{|c|c|c|c|c|c|}
\hline Summary & ANOVA & \multirow[t]{2}{*}{ Dimensions } & \multirow[b]{2}{*}{$B$} & \multirow[b]{2}{*}{$t$} & \multirow[b]{2}{*}{$P$} \\
\hline $\mathrm{R} \quad \Delta \mathrm{R}^{2}$ & F Sig. & & & & \\
\hline \multirow[t]{3}{*}{.404 .155} & $19.685 \quad .000$ & Environment & .251 & 4.565 & .000 \\
\hline & & Social & -.210 & -3.612 & .000 \\
\hline & & Economy & .275 & 4.541 & .000 \\
\hline
\end{tabular}

We started off by investigating the scenario by using multiple regression analysis for all relationships between TBL dimensions namely; environment, social and economy with sustainability marketing among customers. Since the test is to find out the effect of the relationship between TBL dimensions variables with sustainability marketing. In the regression analysis, multiple regressions were conducted between three independent variables with sustainability marketing. When the combination of independent variables to predict sustainability marketing included environment, social and economy show the results were statistically significant, $\mathrm{F}(3,306)=19.685$, $\mathrm{p}$ $=.000$.

The beta coefficients are presented in Table 4 . Note that environment dimension $(\beta=0.251 ; \mathrm{p}=0.000)$, social dimension $(\beta=-.0210 ; \mathrm{p}=0.000)$ and economy dimension $(\beta$ $=0.275 ; \mathrm{p}=0.010)$ significantly predict sustainability marketing when all three independent variables are included at $5 \%$ at a significant level. Here, the adjusted $\mathrm{R}$ squared value was 0.155 . This indicates that $15.5 \%$ of the variance in sustainability marketing was explained by the model. Meanwhile, the remaining $84.5 \%$ is not affected by the independent variables, which the variables are remained unknown and need further investigation. However, there is statistically significant evidence which supports $\mathrm{H} 1, \mathrm{H} 2$, and H3.

\section{CONCLUSION AND RECOMMENDATION}

This chapter discusses the finding from the analysis presented in the previous chapter and related them to the above mentioned objectives of this research which is to identify the relationship between Triple Bottom Line which is environmental, social and economy with the Sustainability Marketing among TER customer. Based on the discussion, researchers also suggest several recommendations to benefit the area of study.

The discussion is based on both research objectives:

a) To investigate the relationship between environment and sustainability marketing.

b) To investigate the relationship between social and sustainability marketing.

c) To investigate the relationship between economy and sustainability marketing.

\section{A. Conclusions}

In summary, the results of this study are worthwhile not only for Terengganu Equestrian Resort (TER) customers but also for others people to have clearer perception towards sustainability marketing in their life. With this knowledge, individuals can suggest to others people for them to have positive perception towards sustainability marketing and at the same time help to protect the environment.

The researcher thinks by support the eco-friendly product can help individuals to save money because some eco-friendly product gives more benefit if compare to not eco- friendly product.

\section{B. Recommendations}

There are three recommendations that researcher could suggest for the future research. Firstly is to expand the sample size. A bigger sample size can be used around 500-1000 respondents. The bigger sample can give more reliability and validation for the data analysis and to ensure an equitable number of males and females in the experimental and control groups so as to minimize gender bias in the results. Next is to implement this study in the other places. The researcher suggests that the next research investigation can be done at any other places. From the finding, we can see how much the similarity and difference occur and exist between the studies. Finally is, to extend this study to the other dimension. The researcher suggests doing more research about sustainability marketing to make a comparison of research study of existing with the future research.

\section{References}

[1] D. Maeve, "Sustainability Marketing - what it is and examples of best practice" 2013. Retrieved from Origin Green Blog http://blog.origingreen.ie/2013/08/20/sustainability-marketing-what-itis-and-examples-of-best-practice/

[2] Michelle M. (n.d.). Sustainability vs. CSR: What's Best for You? (n.d). Retrieved 
fromhttp://hotelexecutive.com/business_review/3465/sustainability-vscsr-whats-best-for-you

[3] Mingguan Malaysia. 2014, Kuala Lumpur, 7 December 2014.

[4] R. Krecjie and D. Morgan, "Determining Sample Size for Research Activities".Educational and Psychological Measurement, 30, p. 607610,1970

[5] S. Kamaljit, "Has marketing come full circle? Demarketing for sustainability". Journal of Emerald Group Publishing Limited, VOL. 12 NO. 4, pp. 177-185, 2011. DOI 10.1108/ 17515631111155133

[6] P. Kotler and G,Armstrong,"Principles of Marketing", 10th edition,New Jersey 2004.

[7] F.M. Belz, "Sustainability Marketing. Blueprint of a Research Agenda", Discussion paper No. 1, Marketing and Management in the Food Industry, Freising. 2005

[8] F. M. Belz and K. Birte, " Strategic and Instrumental Sustainability Marketing in the Western European Food Processing Industry:Conceptual Framework and Hypotheses". 200

[9] N. Alex and C. Sungchul, "Environmental and Economic Dimensions of Sustainability and Price Effects on Consumer Responses". Joural Of Business ethics 104:269-282, DOI 10.1007/s10551-011-0908-8. 2011
[10] F.S. Timothy and J.H. Tanya, “ The Triple Bottom Line: What Is It and How Does It Work”. Journal of Indiana University Kelley School of Business 4-8, 2011

[11] B, Eileen, " Definitions for Social Sustainability and Social Work Paper". Retrieved from http://www.cswe.org. 2009

[12] R, Gilbert, R. Stevenson, D.H. Girardet and R. Stren, “ Making cities work: The role of local authorities in the urban environment. London: Earthscan" 1996

[13] J. Peter, C.H. Colin, C. Daphne, and H, David,“ Viewpoint Marketing and sustainability. (pp. 123-130) 2007. DOI 10.1108/02634500810860584

[14] Stephen M. (2004) SOCIAL SUSTAINABILITY : TOWARDS SOME DEFINITIONS, 27, 2004. Retrieved from http://www.hawkecentre.unisa.edu.au/institute/

[15] U. Sekaran, "Research methods for business: a skill building approach", 4th edition, New York, John Wiley \& Sons Inc, 2009.

[16] Hair .J.F, Ringle, C.M., and M. Sarstedt. PLS-SEM. Indeed a Silver Bullet. The Journal of Marketing Theory and Practice, 19(2), 129-52. doi:10.2753/MTP1069-6679190202. 2013. 